\title{
Front Matter: Volume 10561
}

, "Front Matter: Volume 10561," Proc. SPIE 10561, Next-Generation Optical Communication: Components, Sub-Systems, and Systems VII, 1056101 (13 June 2018); doi: 10.1117/12.2319344

SPIE. Event: SPIE OPTO, 2018, San Francisco, California, United States 


\title{
PROCEEDINGS OF SPIE
}

\section{Next-Generation Optical Communication: Components, Sub-Systems, and Systems VII}

\author{
Guifang Li \\ Xiang Zhou \\ Editors
}

29-31 January 2018

San Francisco, California, United States

Sponsored by

SPIE

Cosponsored by

Corning Incorporated (United States)

NTT Electronics (Japan)

Published by

SPIE 
The papers in this volume were part of the technical conference cited on the cover and title page. Papers were selected and subject to review by the editors and conference program committee. Some conference presentations may not be available for publication. Additional papers and presentation recordings may be available online in the SPIE Digital Library at SPIEDigitalLibrary.org.

The papers reflect the work and thoughts of the authors and are published herein as submitted. The publisher is not responsible for the validity of the information or for any outcomes resulting from reliance thereon.

Please use the following format to cite material from these proceedings:

Author(s), "Title of Paper," in Next-Generation Optical Communication: Components, SubSystems, and Systems VII, edited by Guifang Li, Xiang Zhou, Proceedings of SPIE Vol. 10561 (SPIE, Bellingham, WA, 2018) Seven-digit Article CID Number.

ISSN: 0277-786X

ISSN: 1996-756X (electronic)

ISBN: 9781510616073

ISBN: 9781510616080 (electronic)

Published by

SPIE

P.O. Box 10, Bellingham, Washington 98227-0010 USA

Telephone +1 3606763290 (Pacific Time) · Fax +1 3606471445

SPIE.org

Copyright (c) 2018, Society of Photo-Optical Instrumentation Engineers.

Copying of material in this book for internal or personal use, or for the internal or personal use of specific clients, beyond the fair use provisions granted by the U.S. Copyright Law is authorized by SPIE subject to payment of copying fees. The Transactional Reporting Service base fee for this volume is $\$ 18.00$ per article (or portion thereof), which should be paid directly to the Copyright Clearance Center (CCC), 222 Rosewood Drive, Danvers, MA 01923. Payment may also be made electronically through CCC Online at copyright.com. Other copying for republication, resale, advertising or promotion, or any form of systematic or multiple reproduction of any material in this book is prohibited except with permission in writing from the publisher. The CCC fee code is 0277$786 \mathrm{X} / 18 / \$ 18.00$.

Printed in the United States of America.

Publication of record for individual papers is online in the SPIE Digital Library.

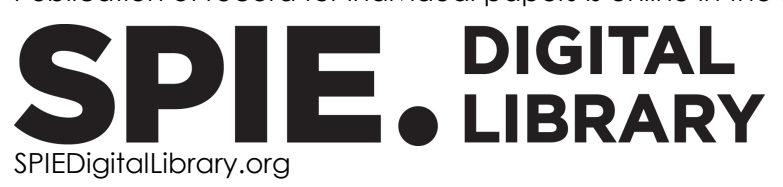

Paper Numbering: Proceedings of SPIE follow an e-First publication model. A unique citation identifier (CID) number is assigned to each article at the time of publication. Utilization of CIDs allows articles to be fully citable as soon as they are published online, and connects the same identifier to all online and print versions of the publication. SPIE uses a seven-digit CID article numbering system structured as follows:

- The first five digits correspond to the SPIE volume number.

- The last two digits indicate publication order within the volume using a Base 36 numbering system employing both numerals and letters. These two-number sets start with $00,01,02,03$, 04, 05, 06, 07, 08, 09, OA, OB ... 0Z, followed by 10-1Z, 20-2Z, etc. The CID Number appears on each page of the manuscript. 


\title{
Contents
}

\author{
$\checkmark \quad$ Authors \\ vii Conference Committee
}

TX/RX I

$1056104 \quad$ Flexible optical transceivers (Invited Paper) [10561-3]

1056105 High-responsivity L-band micro intradyne coherent receiver using InP-based photodetector integrated with $90^{\circ}$ hybrid [10561-4]

1056107 Optical terabit transmitter and receiver based on passive polymer and InP technology for high-speed optical connectivity between datacenters (Best Student Paper Award) [10561-6]

TX/RX II

1056109 Frequency offset locked dual-carrier excitation of phase-modulated electro-optic frequency combs for bandwidth scaling and nonlinear spectral broadening [10561-8]

10561 OB Kramers-Kronig coherent receiver (Invited Paper) [10561-10]

SDM AND FSO I

10561 OC High-capacity transmission with homogeneous multi-core fibers and wideband optical comb sources (Invited Paper) [10561-11]

10561 OD Measurement of differential mode delay using reference-free low-coherence digital holography [10561-12]

10561 OE Measurement of differential modal group delay of few-mode fibers using four-wave mixing [10561-13]

10561 OF Advanced chip package of a fiber-coupled superconducting single-photon detector for a closed-cycle cryostat [10561-17]

SDM AND FSO II

$10561 \mathrm{OH}$ Selective spatial mode attenuator using phase-intensity-phase modulation toward modedivision multiplexing transmission [10561-15]

10561 Ol MIMO-free space-division-multiplexing for data center applications [10561-16] 
10561 0J Precision optical components for lidar systems developed for autonomous vehicles [10561-18]

10561 OK Laser pointing sensor system for beaconless lasercom [10561-19]

FIBER AND TRANSMISSION SYSTEMS I

10561 OL Approaching Shannon capacity limit using coded modulation (Invited Paper) [10561-21]

$105610 \mathrm{M}$ Accurate model to predict performance of coherent optical transponder [10561-22]

10561 ON G.654.E optical fibers for high-data-rate terrestrial transmission systems with long reach (Invited Paper) [10561-23]

FIBER AND TRANSMISSION SYSTEMS II

10561 OP Ultra-low loss Ge-free silica core fiber for submarine transmission (Invited Paper) [10561-25]

$105610 Q$ Wave-band multiplexed 20-Gb/s QPSK simultaneous transmission over 4-km holey fiber in O- and T-bands with homodyne detection [10561-26]

10561 OR Entropy loading for multi-carrier optical systems (Invited Paper) [10561-27]

10561 OS Flexible optical transmission: M-QAM, hybrid formats, and probabilistic shaping (Invited Paper) [10561-28]

POSTER SESSION

10561 OT On the use of visible light communication in cooperative vehicular communication systems [10561-29] 


\title{
Authors
}

Numbers in the index correspond to the last two digits of the seven-digit citation identifier (CID) article numbering system used in Proceedings of SPIE. The first five digits reflect the volume number. Base 36 numbering is employed for the last two digits and indicates the order of articles within the volume. Numbers start with 00, 01, 02, 03, 04, 05, 06, 07, 08, 09, OA, OB...0Z, followed by 10-12, 20-2Z, etc.

\author{
Aimone, A., 07 \\ Anderson, Jon, OM \\ Antonelli, Cristian, OB \\ Avramopoulos, H., 07 \\ Awaji, Y., OC \\ Bach, H.-G., 07 \\ Batshon, Hussam G., OL \\ Boitier, F., 07 \\ Buchali, Fred, OS \\ Chandrasekhar, Sethumadhavan, OB \\ Che, Di, OR \\ Chen, Xi, OB \\ Chesworth, Andrew A., OJ \\ de Felipe, D., 07 \\ De Pedro, Hector, ON \\ Downie, John D., ON \\ Dupuy, J.-Y., 07 \\ Fujimura, Yasushi, 05 \\ Goto, Yuta, OD \\ Groumas, P., 07 \\ $\mathrm{He}$, Xuan, $\mathrm{OM}$ \\ Hoshino, Shogo, OD \\ Huddleston, Jeremy, OJ \\ Hurley, Jason, ON \\ Jacoby, Marc T., OK \\ Jennevé, P., 07 \\ Johansen, T. K., 07 \\ Jorge, F., 07 \\ Kanno, Atsushi, $0 Q$ \\ Katopodis, V., 07 \\ Keil, N., 07 \\ Kelkar, Varun, OE \\ Kermann, M., OF \\ Konczykowska, A., 07 \\ Kouloumentas, Ch., 07 \\ Kuo, B. P. P., OC \\ Kurokawa, Munetaka, 05 \\ Li, An, OR \\ Li, Guifang, OI \\ Louro, P., OT \\ Luís, R. S., OC \\ Makovejs, Sergejs, ON \\ Marciante, J., OC \\ Mardoyan, H., 07 \\ Mecozzi, Antonio, OB \\ Mlejnek, Michal, ON \\ Möller, Ch., OF \\ Nagarjun, K. P., 09 \\ Neckermann, K., OF
}

\author{
Ogawa, Kazuhisa, OD, $\mathrm{OH}$ \\ Okamoto, Atsushi, OD, OH \\ Ortlepp, T., OF \\ Pagano, A., 07 \\ Prakash, Roopa, 09 \\ Puttnam, B. J., OC \\ Quagliotti, M., 07 \\ Rademacher, G., OC \\ Radic, S., OC \\ Renaudier, J., 07 \\ Rios-Müller, R., 07 \\ Roberts, Kim, 04 \\ Roccato, D., 07 \\ Sakaguchi, J., OC \\ Sakurai, Kenji, 05 \\ Selvaraja, Shankar Kumar, 09 \\ Shieh, William, OR \\ Shimizu, Shimpei, $\mathrm{OH}$ \\ Shtaif, Mark, OB \\ Singh, Ajay, 09 \\ Sotobayashi, Hideyuki, 0Q \\ Spyropoulou, M., 07 \\ Suparna, S., 09 \\ Supradeepa, V. R., 09 \\ Swain, Smaranika, OE \\ Swank, Aaron J., OK \\ Takechi, Masaru, 05 \\ Tamura, Yoshiaki, OP \\ Tienforti, M., 07 \\ Tomita, Akihisa, OD, $\mathrm{OH}$ \\ Tsokos, C., 07 \\ Tsuritani, Takehiro, OD, $\mathrm{OH}$ \\ Vannucci, A., 07 \\ Venkitesh, Deepa, OE \\ Vieira, M. A., OT \\ Vieira, M., OT \\ Vieira, P., OT \\ Vikram, B. S., 09 \\ Vovan, Andre, OM \\ Wada, N., OC \\ Wakayama, Yuta, OD, $\mathrm{OH}$ \\ Wang, Qiang, OM \\ Wang, Wei, ol \\ Winzer, Peter J., OB \\ Yagi, Hideki, 05 \\ Yamada, Shoko, $0 Q$ \\ Yamamoto, Naokatsu, $0 Q$ \\ Yang, Zhiqun, ol \\ Yoneda, Yoshihiro, 05
}


Yu, Huang, OI

Yue, Yang, $O M$

Zhang, Lin, Ol

Zhang, Yichi, Ol

Zhao, Jian, 0 I

Zhou, Zihan, $\mathrm{OH}$

Proc. of SPIE Vol. 10561 1056101-6

Downloaded From: https://www.spiedigitallibrary.org/conference-proceedings-of-spie on 26 Apr 2023 Terms of Use: https://www.spiedigitallibrary.org/terms-of-use 


\title{
Conference Committee
}

\author{
Symposium Chairs
}

Connie J. Chang-Hasnain, University of California, Berkeley (United States)

Graham T. Reed, Optoelectronics Research Centre, University of Southampton (United Kingdom)

Symposium Co-chairs

Jean-Emmanuel Broquin, IMEP-LAHC (France)

Shibin Jiang, AdValue Photonics, Inc. (United States)

Program Track Chair

Benjamin B. Dingel, Nasfine Photonics, Inc. (United States)

Conference Chairs

Guifang Li, CREOL, The College of Optics and Photonics, University of Central Florida (United States)

Xiang Zhou, Google (United States)

Conference Program Committee

Kazi S. Abedin, OFS Fitel LLC (United States)

Jin-Xing Cai, TE SubCom (United States)

Hwan Seok Chung, Electronics and Telecommunications Research Institute (Korea, Republic of)

Benjamin B. Dingel, Nasfine Photonics, Inc. (United States)

Ezra Ip, NEC Laboratories America, Inc. (United States)

Yongmin Jung, University of Southampton (United Kingdom)

Inuk Kang, NOKIA Bell Laboratories (United States)

Tsuyoshi Konishi, Osaka University (Japan)

Ming-Jun Li, Corning Incorporated (United States)

Chao Lu, The Hong Kong Polytechnic University (Hong Kong, China)

Akihiro Maruta, Osaka University (Japan)

Takashi Sasaki, Innovation Core SEl, Inc. (United States)

Siyuan Yu, University of Bristol (United Kingdom)

Yanjun Zhu, Huawei Technologies Company, Ltd. (United States) 


\section{Session Chairs}

1 Optical Communication Keynote Session: Joint Session with Conferences 10559 and 10561

Guifang Li, CREOL, The College of Optics and Photonics, University of Central Florida (United States)

Benjamin B. Dingel, Nasfine Photonics, Inc. (United States)

$2 \operatorname{Tx} / \mathrm{Rx}$

Colin J. McKinstrie, Huawei Technologies Company, Ltd. (United States)

$3 \mathrm{Tx} / \mathrm{Rx} \|$

Benjamin J. Puttnam, National Institute of Information and Communications Technology (Japan)

4 SDM and FSO I

Hussam G. Batshon, TE Connectivity Subsea Communications (United States)

5 SDM and FSO II

Cristian Antonelli, Università degli Studi dell'Aquila (Italy)

6 Fiber and Transmission Systems I

Di Che, The University of Melbourne (Australia)

$7 \quad$ Fiber and Transmission Systems II

John D. Downie, Corning Incorporated (United States) 